\title{
THE CONCEPT OF “RELIGIOUS TERM” AND ITS BASIC FEATURES
}

\author{
Marta-Dzvenyslava Mykytka \\ Postgraduate Student, Ivan Franko National University of Lviv, Ukraine \\ e-mail: martha_mikitka@ukr.net, orcid.org/0000-0002-2734-8272
}

\section{Summary}

The article deals with the problem, which has attracted scholars' attention in the field of terminology during the last several decades, namely the concept of the term and its common basic features. Although a lot of studies have focused on this issue, there is no precise definition and common understanding of the term. Having examined some previous works on the topic, we revealed that the wide range of different approaches to the problem are available. That is why the aim here is to investigate the concept of "religious term", its features and functioning.

First of all, we have studied the common signs of the term, which are put forward in terminology and analysed the inconsistency of these features with real terms. We suggest that there is no ideal term at all, as a big amount of terms do not always meet the necessary requirements.

As a result, we assume that the Latin religious terms are not entirely "successful". They are systemic, definitive and have a special scope. On the other hand, religious terms are often polysemic, inaccurate, metaphorical and have a lot of synonyms.

Keywords: definition of the term, ideal term, non-compliant term, basic features, necessary requirements.

\section{DOI https://doi.org/10.23856/4104}

\section{Introduction}

Numerous scholars have focused their attention on the problem of basic signs, features and requirements for the terms in terninology. In particular, such scholars as S. Gryniov-Grynevych, V. Vinokur, B. Golovin, A. Zagnitko, V. Gak, M. Vakulenko and others have dealt with this issue.

Some studies of the features and requirements for the terms were based on the material of separate terminological systems: I. Boyko (terms of cosmetology), M. Salamakha (terms of environmental protection), G. Gregul (legal terms).

Latin religious terminology is of particular interest because of the lack of scientific papers that would investigate it more broadly.

One of the major aims of this work is to examine definition of signs and requirements to terms. With this aim in mind, the article presents the concept of the "term" in general and the concept of the "religious term" as well. In brief, we compare different approaches to understand what "religious terms", "sacred terms", "theological terms" actually are. Finally, we conclude that religious terms are quite non-compliant.

In linguistics, there are two approaches to the term: structural-substantial and functional. Structural-substantial approach provides an understanding of the term as "a special word that exists within a particular industry and which, in contrast to the common word, has a number of special features: accuracy, conciseness, unambiguity, stylistic neutrality etc" (Superanskaya, 1989). Supporters of this approach were D.S. Lotte, T. Kandelaki, T. Kiyak.

Unfortunately, the main disadvantage of the substantial approach is the inconsistency of most of the terms with certain features, their deviation from the norm, and therefore, in 
linguistics was defined a functional approach (V.G. Gak., V. Vinokur, B. Golovin, V. Leichik, S. Gryniov-Hrynevych, A. Zagnitko, I. Kochan, I. Kvitko and others). According to the functional approach, the term is not a special word, but "function, type of use of the lexical unit" (Gak 1971: 68).

We support the second one and consider the terms in our study in the context of the functional approach.

\section{What is religious term?}

Despite the variety of definitions of the "term" in linguistics, it seems to be no general definition. This is primarily caused by the lack of clearly defined characteristics, as a result of which each scholar understands this phenomenon in his own way (Statsyuk, 2016: 113). Therefore, we are going to provide the most common definitions of the term.

As reported by V.A. Tatarinov, the term is a linguistic sign (word or phrase), which corresponds to a special concept, phenomenon or object (Tatarinov, 1996: 157).

O. Selivanova points out that the term is a word or a phrase that denotes the concept of a special sphere of communication in science, production, technology, art or in a particular field of knowledge or human activity (Selivanova, 2006: 617).

O. Shmelyova interprets the term as a unit of national language, which simultaneously belongs to a special language subsystem and therefore acts as a special language unit, which names special and professional concepts, which allows to distinguish them among other units of the language system (Shmelyova, 2010: 10).

A well-known Ukrainian terminologist E. F. Skorokhodko claims that a term is a word or established phrase that expresses a special concept of science, technology or other field of human activity, and has a definition that reveals the features of this concept which are relevant to this area (Skorokhodko, 2006: 7).

In our opinion, I. Kvitko offers a comprehensive definition of the term: "A term is a word or verbal complex that correlates with the concept of a certain organized field of knowledge (science, technology), which enters into a systemic relationship with other words and verbal complexes, forms together with them in each case and at a certain time a closed system characterized by high informativeness, unambiguity, accuracy and expressive neutrality" (Kvitko, 1976: 21).

According to the above definitions, "term" is considered to be a special word or phrase that is used to denote a special concept of a particular field of science or technology.

It is worth noting that the scholars, who study religious terms, distinguish between the concepts of "sacred term", "theological term", "religious term".

Sacred terms are the names of religious ideas, concepts and categories, as well as the names of actions, processes, objects, symbols and subjects of religious practice (Dictionary of Ponomarev, 2001: 72). The concept of "sacred term" (which comes from the Latin word "sacer" - "holy, sacred"), as it is noted by M. Veresh, is used in the context of Scripture and worship and has a limited scope (Veresh, 2013: 104).

We hold the view that the concept of "sacred term" is more appropriate to use in relation to the characteristics of phenomena and objects of religious worship, sacraments, places of religious worship, objects of church use, because we often understand these concepts as "sacred" or "those intended for gods (God)".

Theological (Christian-theological) term (M. Veresh, L. Zakrenytska) refers to the science of theology, because it reflects the essence of theological realities, and the words that denote them are Christian-theological terms (Veresh, 2016: 23). The theological term also has 
a certain semantic limitation, as it describes and denotes only those concepts that are related to Christianity.

Religious term refers to the widest range of religious concepts and refers to any religion in the world or not (atheism, agnosticism, sect, etc.). For example, within the studied Latin religious terminology, we also single out terms-mythologies, terms-paganisms.

In agreement with E. Zhernovey, a religious terminological unit is defined as a word or verbal complex that correlates with the concept of any religion or religious science, enters the systemic relationship with other similar words or verbal complexes and forms a closed system with them, which is usually characterized by high informativeness, accuracy and neutral expressiveness (Zhernovey, 2003: 5).

Interestingly, some scholars distinguish more narrowly specialized concepts within the religious term, for instance "church-religious term" (I. Vorona, A. Kovtun, S. Bibla); "churchritual term" (N. Puryaeva); "liturgical and ritual vocabulary" (Yu. Osinchuk).

Conforming to the above definitions, the studied "religious term" will be defined as a word or phrase that denotes a special concept or object of the religious sphere, namely: religious ideas, concepts, categories, as well as the names of actions, processes, objects, symbols and subobjects of religious practice, proprial names.

\section{Requirements for the term in terminology}

Researchers interpret and define the features and requirements for the term in a different manner, so we present the most well-known and generally accepted in linguistics.

According to W. Schmidt, the term must have such properties as professional orientation, content, accuracy, unambiguity, brevity, as well as aesthetic, expressive and modal neutrality (Schmidt, 1969: 12).

S. Gryniov-Grynevych lists the following requirements: notation, belonging to a special field of knowledge, definitiveness, meaning accuracy, contextual independence, conventionality and purposeful nature of appearance, stability and reproduction in language, nominativeness, stylistic neutrality (Grinev-Grinevich, 2008: 30).

O.S. Petryna, in her investigation into the functioning of English and Ukrainian terminology of the banking sector, lists the following requirements for the terms:

1) connection with the scientific concept; 2) the presence of a clear definition; 3) systemicity; 4) special scope; 5) the tendency to unambiguity within the terminological field; 6) relative independence from the context; 7) the term must be accurate, clear; 8) the term must be short (concise), semantically transparent; 9) it is important for the term to avoid synonyms and homonyms; 10) plan of expression - a word or phrase; 11) stylistic neutrality; 11) the term tends to melodiousness (Petryna, 2016: 17-18).

Many scholars also adhere to the correspondence "one concept - one term". We consider it is crucial to note that it is an ideal scheme rather than a statement of the real state of affairs. Usually, one term can express different meanings and concepts, therefore a lot of terms are polysemic.

Obviously, these assertions seem to be reasonable and acceptable if to speak of an ideal term. That is why several remarks should be highlighted to the given requirements, namely: 1) not all terms are systemic (have clear genealogical connections and sufficient wordforming potential); 2) most of the above features and characteristics are inherent only to "successful" terms; 3) the criterion of neutrality / expressiveness is not always appropriate (Vakulenko 1996: 25-26). 


\section{The main features of the religious term}

We highlight the following main features of the term:

1) nominativeness. The term belongs to a special field of use due to the fact that it is used to name (names, nominations) concepts. This property of the term is the most important, because it determines not only the belonging of the term to a certain field of knowledge, but also all its other properties (Grinev-Grinevich, 2008: 26-27).

2) unambiguity or a tendency to unambiguity. It is necessary for terms to be monosemic, therefore ambiguity is traditionally considered to be negative and unacceptable phenomenon in terminology. However, the unambiguity of the term is rather an ideal, because polysemy is quite common both in common vocabulary and in scientific language. A large number of new terms are formed precisely due to semantic term formation, and hence change their meanings or add new ones.

In particular, religious terminology is also characterized by the phenomenon of polysemy, where one lexeme expresses different concepts for common and scientific language.

Thus, for example, the term lexeme "oblatio" is ambiguous, where the first meaning is "immolation / sacrifice", and the second meaning is "liturgy / church service"; the term "memoria" is used in common language in the meaning of "memory", and in religious terminology has developed another meaning - "grave" etc.

3) lack of synonyms and homonyms. The ideal term should be precise and unambiguous, so there should be no synonyms. However, "the ability of polysemic terms to belong to different paradigmatic series leads to the emergence of synonymous, antonymous and homonymous relations" (Zakrenytska, 2011: 29).

A study of the Latin religious terminology has shown that synonymous relations are frequent, for instance: lavacrum (Per. Aeth. XLV, 4) / baptismum (Per. Aeth. XLV, 4) / aqua sancta (Conf, $I X, 2)$ - these three terms are equally used to denote the concept of "baptism"; operatio (Per. Aeth. XXIV, 7) / oblatio (Per. Aeth. IV, 3) / missa (Per. Aeth. XLIII, 3) mean "worship"; affigentes (Conf, VIII, 6) / neofiti (Per. Aeth. XLVII) - both terms have the meaning of "new converts" > people who have just become Christians; votum (Conf, VI, 2) / oratio (Per. Aeth. IV, 3) / prex (Conf, IV, 3; V, 9) - all three tokens denote the concept of "prayer" etc.

4) accuracy. The term must fully and accurately convey the essence of the concept it denotes. This means that the length of the term should be sufficient to denote the concept and sufficient to distinguish it from similar concepts (Salamakha 2014: 50).

The exact term does not have to be short and monosyllabic. Composite terms and multicomponent terms in terminology are the best way to convey information and reflect the features of the term more accurately, because they contain additional component (sometimes several ones) which specifies the meaning of another: dies dominica > Sunday / dies dominica paschae (Per. Aeth. XL, 2) > Easter Sunday; missa > service, worship / missa matutina (Per. Aeth. XLVI, 1) - morning service / missa lucernaris (Per. Aeth. XXV, 6) - evening service.

5) motivation. As a result of motivation, language signs are used to convey term concepts by giving them a new, terminological meaning or by constructing new signs (Zanizdra, 2007: 99).

A detailed definition of motivation is given by M. N. Yantsenetska, who by word-forming motivation means the ability of a word to express the internal formal semantic organization on the basis of its dual (basic and formal) correlation, which reflects methods and means of transmitting verbal information, available in language (Yantsenetska, 1979).

The difference between morphological and semantic motivation can be traced on the example of complex word-terms, where the main meaning is "semantic reading", and structural 
characteristics are less important (I. Boyko, 2018: 39). The most complete expression of the motivation of the term is its systemicity - semantic transparency, which allows to form an idea of the concept called the term (Grinev-Grinevich, 2008: 34).

6) systemicity. Each term operates within a certain terminology, has its own specific place and expresses its terminological meaning. Outside the terminology, the term can take on other meanings or nuances. One of the signs of the systematic nature of terms is the reflection of the origin and development of the terminological system in which they exist and functionate, form terminological nests.

To begin with, a terminological nest is understood as a set of terms united around one common nuclear component. Terminological nests are formed as a result of a syntactic method of term formation, in the process of which "the main component acquires the status of definition, and vice versa, the defining component of the term - the status of the basic component of the derived nomination" (Kazarina, 1998: 154). For example, the term liber is a nuclear component of such terminological units as: libri ecclesiastici - Church books, divini libri - Holy books, liber Genesis - Book of Genesis, liber Deuteronomii - Book of Deuteronomy, libri tui - Your Books (God's Books), liber regnorum - Book of the Kingdoms, Manichei libri-Manicheans' books etc.

The lexeme ecclesia forms the nest of the terms > ecclesia Chrysti - Church of Christ, ecclesia unica - One Church, ecclesia grandis - a big church, ecclesia catholica - Catholic Church.

Systematic terminology is closely combined with the concept of classification. Through the classification scheme the logical-conceptual structure of the subject branch in the set of its connections is revealed and illustrated (Zakrenytska, 2011: 7).

7) definiteness of the term. The term differs from the commonly used word in that way, that in common vocabulary the boundaries between the words meanings may be unstable, while terms highlight their semantic boundaries clearly. That is why definiteness is one of the main requirements to the term, because it helps the term correlate with a specific concept.

As noted by A.V. Lemov, the presence of the term definition is an important condition for distinguishing it from the general literary word, as well as for the creation, storage and transmission of scientific information (Lemov, 2000: 42): caelibatus (Conf, VI, 3) - celibacy "compulsory celibacy introduced for the Catholic clergy and Orthodox monasticism"; pentecoste (Per Aeth XXV, 6) - Pentecost - "50th day after Easter"; ieiunium (Per. Aeth. XXVIII, 3) - fast / fasting - "abstinence from sins and food for a certain period of time" etc.

8) stylistic neutrality. Terminology strives for the accuracy and unambiguity of the term, and hence for stylistic neutrality, the absence of emotionally expressive coloring. The term must not be figurative, must not cause additional figurative representations, only be limited to a clear scientific concept.

However, according to M.O. Vakulenko, stylistically neutral terms are not necessarily the most appropriate. The differences between artistic and scientific style, between literature and terminology are not so significant as to completely contrast them (Vakulenko, 2010: 54).

The secondary nomination is a result of the creation of a large proportion of the studied terms, because religious terminology is characterized by expressiveness and numerous symbolisms and is filled with stylistically marked terms - metaphors and metonyms: terra repromissionis (Per. Aeth. XII, 5) - Promised Land; terra sancta (Per. Aeth, V, 2) - Holy Land; arbor veritatis (Per, Aeth. VIII, 4) - Cognitive Tree; caelestis imperator (Conf, VII, 21) - King of Heaven; spiritalis mater nostra (Conf, VII, 1) - our spiritual mother (Church); tortuosae viae (Conf, VI, 16) - thorny path; regnum uxorium (Conf, VI, 15) - Kingdom of Marriage; memoriae sanctorum (Conf, VI, 2) - memorial service etc.

9) brevity and conciseness. The shortness of the term in terminology is rather a desirable feature, because cumbersome terms are not easy to use and remember. Structural analysis of the 
religious terminology system proves that the largest share is occupied by one-word terms (root and derivatives) and 2-3 component constructions.

Multicomponent constructions consisting of 4 or more components are not widely used in the studied terminology, what is a positive phenomenon.

\section{Conclusions}

The most satisfactory conclusion that we can come to is that a sample of the studied Latin religious terms shows that these terms have all the necessary features and meets all the needs, which are important for terminology: they are systemic, have a definition, have a special scope, partially have the features of accuracy, unambiguity, brevity. On the other hand, the studied terms are characterized by a high degree of stylictic coloration, what is a relative disadvantage.

The analysis also confirmed that Latin religious terms are not fixed, but are functional, mobile. This means that the term functions freely within the functional-semantic field, can be a constituent of the nuclear sphere, perinuclear, have features of both commonly used word and scientific term.

In view of this, the prospect of further research is the consideration and study of the functional features of the term, the peculiarities of its existence within the lexical-semantic field, the division of Latin religious terms into thematic and lexical-semantic groups.

\section{References}

Boiko, I. I. (2018). Osnovni oznaky ta vymohy do termina haluzei kosmetolohii ta estetychnoi medytsyny [The main features and requirements for the term branches of cosmetology and aesthetic medicine]. Lviv: Lvivskyi filolohichnyi chasopys. Vol. 3. pp. 36-41. [in Ukrainian]

Vakulenko, M. O. (2010). Termin i terminolohiia: osnovni polozhennia ta metody doslidzhennia [Term and terminology: basic principles and research methods]. Problemy semantyky slova, rechennia ta tekstu. Vol. 25. pp. 52-68. [in Ukrainian]

Veresh, M. T. (2013). Zahalna linhvistychna kharakterystyka khrystyiansko-bohoslovskoi terminosystemy [General linguistic characteristics of the Christian-theological terminology]. Terminolohichnyi visnyk. Vol. 2(2). pp. 104-107. [in Ukrainian]

Veresh, M. T. (2016). Leksyko-semantychni ta linhvoprahmatychni osoblyvosti nimetskoi khrystyiansko-bohoslovskoi terminosystemy. (PhD Thesis). Lviv. 215 p. [in Ukrainian]

Gak, V. G. (1971). Assimetriya lingvisticheskogo znaka i nekotorye obshie problemy terminovedeniya [Asymmetry of a linguistic sign and some general problems of terminology]. Moscow: Izd-vo Mosk. Un-ta. Part.1.pp. 68-71. [in Russian]

Grinev-Grinevich, S. V. (2008). Terminovedenie [Terminology] Moscow: Akademiya. 304 p. [in Russian]

Zhernovei, Ye. H. (2003). Relihiina terminolohiia suchasnoi frantsuzkoi movy: geneza, semantyka, funktsionuvannia [Religious terminology of modern French: genesis, semantics, functioning]: Kyiv. 20 p. [in Ukrainian]

Zakrenytska, L. A. (2011). Anhliiska khrystyiansko-bohoslovska terminosystema: henezys, struktura, semantyka [English Christian-theological terminology: genesis, structure, semantics] (PhD Thesis). Khmelnytskyi. 243 p. [in Ukrainian]

Zakrenytska, L. A. (2011). Anhliiska khrystyiansko-bohoslovska terminosystema: henezys, struktura, semantyka [English Christian-theological terminology: genesis, structure, semantics]. Odesa. 20 p. [in Ukrainian] 
Zanizdra, N. O. (2007). Problema motyvovanosti naukovoho termina [The problem of motivation of a scientific term] Visnyk Kremenetskoho nats. un-tu im. M. Ostrohradskoho. Vol. 2 (43). pp. 98 - 102. [in Ukrainian]

Kazarina, S. G. (1998). Tipologicheskie harakteristiki otraslevyh terminologij [Typological characteristics of industry terminologies]. Krasnodar. 276 p.

Kvitko I. S. (1976). Termin v nauchnom dokumente [Term in a scientific document]. Lvov: Vysha shkola. 127 p. [in Russian]

Lemov, A. V. (2000). Sistema, struktura i funkcionirovanie nauchnogo termina [System, structure and functioning of a scientific term]. Saransk: izd-vo Mordov. universiteta. 192 p.[in Russian]

Petryna, O. S. (2016). Formuvannia ta funktsionuvannia anhlomovnykh ta ukrainskykh terminosystem bankivskoi spravy. [Formation and functioning of English and Ukrainian banking terminology] (PhD Thesis). Lviv. 202 p. [in Ukrainian]

Ponomariv, O. D. (2000). Stylistyka suchasnoi ukrainskoi literaturnoi movy [Stylistics of the modern Ukrainian language] Ternopil. 276 p. [in Ukrainian]

Salamakha, M. Ya. (2014). Anhlomovnyi termin sfery okhorony dovkillia ta yoho bazovi oznaky [English-language term of environmental protection and its basic features] Naukovi zapysky Natsionalnoho universytetu "Ostrozka akademiia". Vol. 45. pp. 49-52. [in Ukrainian]

Selivanova, O. (2006). Suchasna linhvistyka: terminolohichna entsyklopediia [Modern linguistics: terminological encyclopedia]: Poltava, Dovkillia-K. 716 p. [in Ukrainian]

Skorokhodko, E. F. (2006). Termin u naukovomu teksti (do stvorennia terminotsentrychnoi teorii naukovoho dyskursu) [Term in a scientific text (to the creation of a terminocentric theory of scientific discourse]: Kyiv. 98 p. [in Ukrainian]

Statsiuk, R. V. (2016). Osnovni pidkhody do vyznachennia poniattia “termin” u suchasnii linhvistychnii nautsi [Basic approaches to the definition of "term" in modern linguistics] Naukovyi visnyk Drohobytskoho derzhavnoho pedahohichnoho universytetu imeni Ivana Franka. Vol. 2. № 5. pp. 112-116. [in Ukrainian]

Superanskaya, A. V. (1989). Obshaya terminologiya: Voprosy teorii [General terminology: Questions of theory] Moscow: Nauka. 243 p.[in Russian]

Tatarinov, V. A. (1996). Teoriya terminovedeniya [Theory of terminology] Moscow: Moskovskij licej. 311 p. [in Russian]

Shmelèva, O. Yu. (2010). Terminologicheskie processy v diahronii i sinhronii (na materiale anglijskogo yazyka) [Terminological processes in diachrony and synchrony]. Sanct-Petersburg: SPbGUEF. 120 p. [in Russian]

Yanceneckaya, M. N. (1979). Semanticheskie voprosy teorii slovoobrazovaniya [Semantic questions of the theory of word formation]. Tomsk: Izd-vo Tomskogo un-ta. 242 p.[in Russian] Schmidt, S. J. (1969). Bedeutung und Begriff: Zur Fundierung einer sprachphilosophischen Semantik. Braunschweig: Vieweg. 176 p. [in German] 